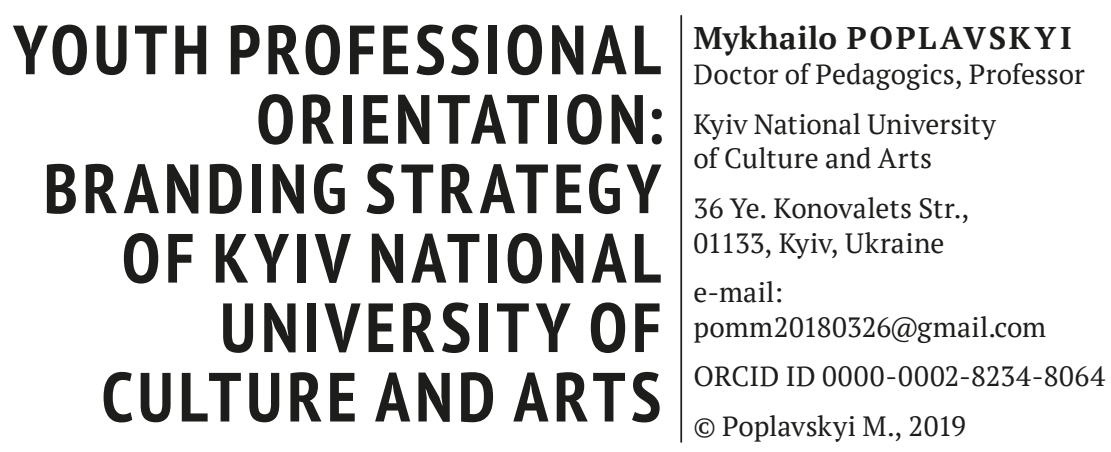

The article is devoted to the actual problem of higher educational establishment brand creating and raising with the help of branding tools and clarifying the peculiarities of professional orientation work as its strategy.

Creation of applied developments and identification of reserves for increasing socio-strategic potential of higher education institutions' brands are of particular relevance nowadays. To enhance the promotion of Kyiv National University of Culture and Arts as a branding strategy, professional orientation work among schools and colleges graduates, has been selected.

Taking into account educational services specificity provided by this higher educational establishment, branding in this sphere can be defined as a set of methods, techniques and ways that enable to bring higher educational establishment developed brand to the consumer of educational services, having formed in his mind the image of this institution and thereby providing effective assistance to the applicant in the perception and analysis of the distinctive features and benefits of an educational institution.

The main objects of higher educational establishment branding are specific products educational service, corporate culture, staff, managers, students and graduates.

KNUC\&A professional orientation work, which has established itself as a strategy for the strengthening of higher educational establishment brand, has its advantages and specifics in comparison with other educational institutions.

Through the personal image of university head, higher educational establishment brand upgrading is taking place.

Professional orientation work as a branding strategy turned out to be a long-term action plan aimed at ensuring and continuously strengthening the commitment and loyalty of the socio-cultural environment to higher education institution. The main common formats of professional orientation are analyzed: mentoring programs, internships, volunteer activity, action "Gap Year".

Key words: brand, branding strategy, professional orientation work, educational service, Kyiv National University of Culture and Arts. 


\title{
ПРОФЕСІЙНА ОРІЄНТАЦІЯ МОЛОДІ: БРЕНДИНГОВА СТРАТЕГІЯ КИЇВСЬКОГО НАЦІОНАЛЬНОГО УНІВЕРСИТЕТУ КУЛЬТУРИ І МИСТЕЦТВ
}

\author{
Михайло Поплавський \\ д-р пед. н., проф. \\ Київський національний університет культури і мистецтв \\ вул. Є. Коновальця, 36, 01133, Київ, Україна \\ e-mail: pomm20180326@gmail.com \\ ORCID ID 0000-0002-8234-8064
}

Стаття присвячена актуальній проблемі створення та підвищення бренда закладу вищої освіти за допомогою інструментарію брендингу та з'ясування особливостей застосування профорієнтаційної роботи як його стратегіï.

Створення прикладних розробок і виявлення резервів підвищення соціально-стратегічного потенціалу брендів закладів вищої освіти нині є особливо на часі. Для підсилення промоції Київського національного університету культури і мистецтв як брендингової стратегії було обрано профорієнтаційну роботу серед молоді, якою $\epsilon$ випускники шкіл і коледжів.

Зважаючи на специфіку освітніх послуг, яку надає цей заклад вищої освіти, брендинг у цій сфері можна визначити як сукупність методів, прийомів і способів, які дозволяють довести розроблений бренд вишу до споживача освітніх послуг, сформувавши в його свідомості імідж цієї установи і тим самим надавши дієву допомогу абітурієнту у сприйнятті та аналізі відмінних особливостей і переваг навчального закладу.

Основними об'єктами брендингу вишу є специфічний продукт - освітня послуга, корпоративна культура, персонал, керівники, студенти та випускники.

Професійно-орієнтаційна робота КНУКіМ, яка зарекомендувала себе як стратегія підсилення бренда вишу, має свої переваги та специфіку у порівнянні з іншими вишами.

За рахунок особистого іміджу керівника вишу відбувається підвищення бренда вищого навчального закладу.

Профорієнтаційна робота як стратегія брендингу виявилася довгостроковим планом дій, який спрямований на забезпечення і постійне зміцнення прихильності та лояльності соціокультурного середовища до вишу. Проаналізовано основні поширені формати профорієнтації: програми менторства, стажування, волонтерської діяльності, акція «Вільний рік».

Ключові слова: бренд, брендингова стратегія, профорієнтаційна робота, освітня послуга, Київський національний університет культури і мистецтв. 


\section{The problem formulation}

During fifty years of activity, Kyiv National University of Culture and Arts has gained a number of distinctive features, first of all, an efficient and prompt response to time challenges that require a holistic implementation and adequate response. Today, university's powerful side and potential opportunity are universally recognized scientific and creative schools, experience of organizing educational process at world level standards, full approved cycle of modern specialists' preparation in the field of culture and arts. However, the most tangible modern challenge is the tight competition in the educational services market. High school constantly needs educational technologies' modernization, there is a clear compliance requirement with European standards of university community development.

The entry of Ukraine into world and European economic, educational and informational space is conditioned by the need to increase competitive position of domestic educational institutions, which depends on the improvement of universities' marketing activities, in particular, using branding tools in the field of social communications, competitive environment and consumers market of educational and scientific services ( Plisenko, 2016).

Now the concept of branding has proven to be one of the most promising ideas for strengthening the image of higher educational establishment. However, in practice, their application generates many new unsolved problems related to branding methodology development, strategies improvement and brand socio-ethical potential strengthening. In particular, there is a shortage of practical experience in brand development, requiring new approaches, tools and models. In this regard, problem statement of studying youth professional orientation as a brand strategy of Kyiv National University of Culture and Arts is relevant.

The purpose of the study is the process of higher educational institution brand forming with the help of branding tools and clarifying the specifics of professional orientation usage as its strategy.

Actual scientific researches and issues analysis

Conceptual and methodological basis of branding theory was established in fundamental works of foreign scholars such as F. Kotler (Kotler F., 2011), A. Willer (Willer, A., 2004), S. Kumber and others. Main models and branding tools are presented in the studies of foreign and domestic experts S. Van Gelder, A. Dlygach, V. Pertsiia, and others.

There are three directions of modern scientific approaches to the essence of professional orientation that have emerged in foreign and Ukrainian science: motivational theories (A. Maslow, F. Herzberg, V. Frumm,); structural theories (E. Ginsberg, N. Axelrod, G. Forsch);"individuality" or "self-understanding development" theories (J. Holland, L. Tyler, D.Super, B.Fedoryshyn). 
Scientific novelty lies in the fact that for the first time on Kyiv National University of Culture and Arts example, features of its brand increasing with the help of professional orientation work as a branding strategy are investigated.

Statement of basic material

Modern educational services market is in difficult economic and demographic crisis. Reducing the number of students for higher educational institutions means reducing its funding by the state, correspondingly, leads to a competitive struggle for educational services consumers. According to $\mathrm{S}$. Semeniuk, educational institution competitiveness is the provision of long-term benefit from educational services consumers, as well as the conquest of a certain market share and ability to resist the redistribution of market in favor of other educational activity subjects (Semeniuk, 2013). Therefore, potential entrants, while choosing a university for study, first of all, think about its authority, image and brand.

So the urgent need is creation of applied developments and identification of reserves for increasing socio-strategic potential of higher educational institutions' brands. At the same time, branding as the world-renowned technological practice of designing and implementing university quality mark implies the presence of a strategy as a certain roadmap, purposefulness and sequence of concerted actions for the long-term perspective, includes a range of reputation or image components in the marketing activity of the university. In particular, in order to strengthen the educational brand of Kyiv National University of Culture and Arts, as a branding strategy, professional orientation work among graduates of schools and colleges was chosen.

Taking into account the specifics of educational services provided by Kyiv National University of Culture and Arts, branding in this sphere can be defined as a set of methods, techniques and ways that allow to bring developed brand of educational institution to educational services consumer, forming in his mind the image of this institution and thereby providing effective assistance to the entrant in the perception and analysis of the distinctive features and benefits of educational establishment. That is, in this context, higher educational institution brand is emerging as a factor in the probable consumers expectation of educational services in obtaining a specific benefit as a result of learning, taking into account not only the receipt of one or the other specialty, but also further career growth (Kucherak, 2013).

Current globalization processes necessitate the need in analysis and critical comprehension of foreign professional orientation experience and possibilities of its introduction into national practice of KNUC\&A professional orientation work.

At the current stage of educational strategies development in Ukraine there is an intensification of professional orientation work, diversification 
of its forms. In addition to traditional tests, questionnaires, consultants on the choice of profession, appeared so-called occupational tuning ("professional audition"). Excursions to educational institutions and various campaigns have become popular, mentoring is developing, professional orientation and career development departments have been opened at schools and universities.

5 popular professional orientation formats are practiced worldwide. We specify them a bit.

1. Theme parks. The most famous of them created Walt Disney (1955) Disney Land, which he turned into a fantastic world of his cartoons heroes into reality. Later, "Disney" company opened the Epcot Park, a model of the world that it will be in the future, combining entertainment and education into a single concept of edutainment. The format of theme parks became used for professional orientation.

The most famous project, the city of professions Kidzania, appeared in Mexico in 1999. Today Kidzania parks exist in 25 cities around the world. It's a huge adult life simulator - a city with corporations and shops, hospitals and universities where you can build a career, work and spend money, learn to work in a team and build a reputation. In the same concept works a small Minicity Park in Ljubljana.

2. Mentoring programs. This is a meeting with a person who has already gone a long way and can share his experience in choosing a university, building a career, life achievements and success.

Interestingly, there are new forms of mentoring: online, speed-mentoring (for appointment with a conditioned mentor one hour is given with a certain periodicity), or, for example, mutual (peer-to-peer) mentoring, when peers or close in education, social level people help each other. This project is actively being implemented at KNUC\&A, in particular, in the work of "Leaders Star Club".

3. Internship. This is perhaps the most popular format of professional orientation - free or paid internship in own country or abroad. For example, Go Overseas project has assembled dozens of existent all-around programs on its site: from studying business in London to work as a translator in Ukraine.

While studying at the university, students have the opportunity to undergo an internship in one of the many metropolitan museums, conduct research in the library, get acquainted with diplomatic missions within a five-week internship at the United Nations Organization, while receiving a scholarship, or teach at school under the supervision of a more experienced teacher.

This practice has been successfully implemented in our university. Thus, in recent years, students have been trained both in Ukraine and in many European countries. In particular, in Verkhovna Rada of Ukraine, V. I. Ver- 
nadskyi National Library of Ukraine, Ministry of Foreign Affairs of Ukraine, embassies of Estonia, India. Within the framework of the memorandum on cooperation with the partner universities, students are trained at Warsaw Management Academy, Danubius University in Galaca (Romania), London Business School “Apsley”, Academy of Theater Arts and Cinema (Tel Aviv, Israel), Budapest Film Academy, The Korda Filmpark in Budapest (Hungary), Academy of Fine Arts in Vienna (Austria), Italian National Film School in Rome (Italy) and others. (Poplavskyi, 2017)

4. Volunteer activity. Unlike internship programs, such programs (volunteer programs) are aimed at solving social problems: teaching children from low-income families, helping non-profit organizations.

Volunteer activity in KNUC\&A is being actively implemented according to the professional orientation direction. Every year university organizes professional orientation tours to schools, colleges of different regions of Ukraine. We invite graduates to visit University of Culture in order to get acquainted with future professions, academic staff and infrastructure of the educational institution. Faculties conduct a preliminary introductory creative competition. To enhance KNUC\&A image, we invite well-known personalities and media faces to become the leaders of the courses, including stage art (A. Seitablaiev, Ostap and Dmytro Stupky, V. Horianskyi, M. Boklan, V. Moiseenko, etc.), musical art (T. Yanytskyi, A. Ivanysh, V. Yesypok, etc.), cinema and television (R. Shyrman, P. Maga, G. Reshetnyk, N. Sharalapova, M. Barnych, O. Balaban, etc.), choreography (G. Chapkis, R. Poklitaru, O. Leshchenko, M. Vantuch, etc.). There is a recruitment for the author's course "PR Sharks", which was introduced by the head of the university.

At the same time, the most active and sociable students are involved in professional orientation campaign, "Applicant headquarters" was created. During the graduates' visit to the university, they tell about the benefits of studying, prospects of realizing themselves in the future profession. Former applicants understand the significance of their actions for future students. Important is the ability to interest, formulate information, pass it on an accessible form to applicants.

KNUC\&A strategic task is talented youth support, development promotion, country talent search and education, based on patriotic attitude towards Alma Mater and Ukraine. That is why project creation for creative specialties "A Talented Entry without a Queue" is organic. Under the condition of the contest for a specified period, the applicant must publish in his social networks his own interesting and original creative work with the hashtag "A Talented Entry without a Queue ". Following the evaluation of contest jury, as a reward, 20 winners receive certificates for studying at the university (Poplavskyi, 2017).

5. "Gap Year". In Europe and the United States, many school graduates take a pause in learning to better understand where to enter, calmly pre- 
pare for submission of documents to the college or the university. Gap year after school is a time when young people personally choose what experience to gain, and various projects provide this assistance.

Considering that in Ukraine the boom of professional orientation initiatives begins, most of the world's formats are hard to reach for young people, in particular, internships, and mentoring still lives within educational institutions or is in the sphere of charitable foundations responsibility.

Consequently, we will identify elements by which KNUC\&A brand was formed and which is intensifying and acquiring new qualities in the process of professional orientation among graduates. The main objects of educational institution branding are educational service, corporate culture, staff, managers, students and graduates.

The quality of educational services is confirmed by highly qualified scientific and pedagogical staff, usage of modern educational technologies, international cooperation, which involves joint research work, internship for teachers, students' practice abroad and others.

Here formed corporate culture and values which based on educational services uniqueness and allow applicants to trust the brand of our university. Corporate values have formed leadership, teachers and students behavior.

All educational process participants are involved with brand building activities, so they are in direct contact with the applicants. A. Wheeler argues that brand content and its ideas need to be explained to employees all the time. Brand creating is the largest investment that an organization can make (Wheeler, 2004).

The main role in branding policy formation belongs to executives because they should convey corporate spirit, enthusiasm to all employees, as well as students, graduates and applicants.

During the long-term branding policy, KNUC\&A leaders form a sense of commitment to higher educational establishment for current students and graduates. This means that then, regardless of any conditions and factors, applicants will try to get education at this university, and after university graduation they will become a tool for brand promoting. For example, Kyiv National University of Culture Arts graduates are proud to receive education here.

For the sake of future and current first-year students "Star Leaders Club" was created. Today in Ukraine there is a great demand for experience, new idea and clear position. The country needs real leaders for whom the most valuable thing is name, reputation and steadfast principles. So, the university's task is to educate such people, help them realize their creative ambitions, and promote their leadership in the chosen profession. "Star Leaders Club" is a startup for successful students and KNUC\&A image project, which runs under the guidance of experienced 
mentors-teachers. The club includes active students - heads of different activity spheres departments: public and political, cultural and artistic, media technologies, PR and journalism, business and service, research, information policy and cyber security, etc.

KNUC\&A professional orientation, which has proven itself as a strategy to enhance university brand, has its advantages and specifics in comparison with others educational establishments. So, every Saturday, Open Days are held for graduates from all regions of the country, who seek to implement in the creative sphere. Meaningful consultations on prestigious specialties, conditions of entry, possibilities of studying in European educational programs are given to applicants. Deans, representatives of scientific and pedagogical staff, creative courses and workshops leaders, students, representatives of self-government bodies are always present at the meetings. Pupils receive promotional products: books, booklets of faculties that cover university activities and demonstrate its capabilities. A"tidbit" of such communication is meeting with KNUC\&A honorary president M. Poplavskyi, who answers all youth questions, motivates for university admission, tells about the specifics of education, prospects in future profession, student life, about the events being held, master classes, active leisure: show programs, entertaining events, concerts and creative meetings, etc.

At present, KNUC\&A has identified an innovative concept of development as a priority area of work. The approach to both students and teaching staff in the modern democratic, professional and strategic direction is completely changing. In particular, the latest education technologies are being introduced, namely: distance education, double diploma, dual education, material and technical base is updated.

Innovative communicative activity is being actively implemented. So, KNUC\&A and all its departments have actively joined social networks Facebook, Instagram, Twitter. Due to the information waves as a managed way of disseminating information to target audiences (rector, vice-rectors, deans have their own accounts), information is disseminated, the university life is comprehensively covered, communication with each student and applicant, as well as with their parents is maintained. For this purpose, there were created "creative groups" of active students.

So, social networks act as a branding tool: they form a positive public opinion about the university, through social networks monitoring, KNUC\&A image and reputation are studied, which makes it possible to have feedback with applicants and students, and it gives the possibility to foresee a reaction to various events and activities, and also find new ways to influence and motivate potential entrants.

An important role in professional orientation work plays University website, which is also a branding tool. It supports university philosophy 
and corporate culture, is constantly updated, has interesting and informative information for entrants.

Very interesting to university entrants is virtual interaction with the university leader, who leads the headings with hashtags \#papa_pohanoho_ne_poradyt (daddy does not advise bad), taking on the role of "father" for a thousand students, whose vocation is to share his experience with young people in the format of minute-videos. Morning headings \#secrets of youth and \#delicious breakfast with Mykhailo Poplavskyi also found their audience. The heading \#nostalgia is past memories, archival photos, video clips of virtual communication initiator. \#Mykhailo_Poplavskyi_asks is a heading created for audience monitoring. Post writers respond to various questions that help to monitor the students' point of view on various topics (Poplavskyi, 2017).

Thus, through the personal image of university head, higher educational establishment brand upgrading is taking place.

As a result, entrants in the choice of educational institution are guided by its image and popularity. At the same time, studying at Kyiv National University of Culture and Arts, students feel their elitism and exclusivity, what future entrants will strive for.

That is, Kyiv National University of Culture and Arts brand causes positive emotions, has a good reputation, is recognizable among other educational institutions of Ukraine and world.

\section{Conclusions}

Consequently, in KNUC\&A, which positions itself as an elite higher education institution, works a professional team that develops, constantly improves special approach to professional orientation and entrants selection, creates special conditions for students' education and training. This confirms the importance of introducing into educational system of innovative programs, marketing technologies and brand building directions. Therefore, professional orientation work as a branding strategy has undeniable advantages. Firstly, it enables higher education institution to provide a permanent refreshment of university entrants who will not need additional motivation for educational services gaining. Secondly, created concept of KNUC\&A branding represents the university as a successful educational institution that has its own cultural and artistic specificity, high rating and recognized not only in Ukraine but also abroad.

Professional orientation work as a branding strategy turned out to be a long-term action plan aimed at ensuring and continuously strengthening the commitment and loyalty of socio-cultural environment to higher educational establishment.

Professional orientation at Kyiv National University of Culture and Arts is successfully implemented, has its own specifics and traditions that meet the modern requirements in educational market. 


\section{REFERENCES}

1. Dunets, L. M. (2013). Formy i metody proforiientatsiinoi roboty u vyshchomu navchalnomu zakladi [Forms and methods of vocational guidance work at a higher educational institution]. Zbirnyk naukovykh prats Khmelnytskoho instytutu sotsialnykh tekhnolohii Universytetu "Ukraina",1(7), pp.8-88 [In Ukrainian].

2. Fukuyama, F. (1989). Teoreticheskie osnovy professional'noy orientatsii [Theoretical foundations of vocational guidance]. Moscow: Moscow State University [In Russian].

3. James, P., Sampson, Jr., Watts, A. G, Palmer, M. \& Hughes, D. (2000). International Collaboration in Translating Career Theory to Practice. The Career Development Quarterly, Vol. 4, pp. 332-339. https://doi.org/10.1002/j.2161-0045.2000.tb00878.x.

4. Kotler, F. (2011). Stratehichnyi marketynh dlia navchalnykh zakladiv [Strategic Marketing for Educational Institutions] M. S. Lylyk \& I. O. Vasylenko, (Trans. in Eng.). Kyiv : Khimdzhest [In Ukrainian].

5. Pivtorak, H. P. (Ed). (2006). Mentor. Suchasnyi slovnyk inshomovnykh sliv [Mentor. Modern dictionary of foreign words]. Kyiv : Dovira [In Ukrainian].

6. Plysenko, H. P. (2016). Brendynh i brend-bildinh yak naivazhlyvishi instrumenty $\mathrm{v}$ konkurentsii na rynku osvitnikh posluh [Branding and brand building as the most important tools in competition in the market of educational services]. Visnyk Kyivskoho natsionalnoho universytetu tekhnolohii ta dyzainu. Seriia: Ekonomichni nauky, 4(101), pp.41-47 [In Ukrainian].

7. Poplavskyi, M. M. (2017). Rektor [Rector]. Kyiv : R.K. Maister-prynt [In Ukrainian].

8. Semeniuk, S. (2013). Brendynh vyshchoho navchalnoho zakladu [Branding of a higher educational institution]. Halytskyi ekonomichnyi visnyk, 3(42), pp.133-138 [In Ukrainian].

9. Watts, A. G. (1997). Strategic Directions for Career Services in Higher Education. Cambridge: AGCAS/NICEC/CRAC. 60 p.

10. Wheeler, A. (2003). Designing Brand Identity: An Essential Guide for the Entire Branding Team. New Jersey : John Wiley \& Sons, Ins., Hoboken.

\section{ЛITЕРАТУРА}

1. Дунець Л. М. Форми і методи профорієнтаційної роботи у вищому навчальному закладі. Збірник наукових праць Хмельницького інституту соціальних технологій Університету «Україна». 2013. № 1 (7). С. 8-88.

2. Котлер Ф. Стратегічний маркетинг для навчальних закладів ; пер. $з$ англ.: Лилик М. С., Василенко І. О. Київ : Хімджест, 2011. 563 с. : іл.

3. Ментор. Сучасний словник іншомовних слів / ред. Г. П. Півторак. Київ : Довіра, 2006. С. 446.

4. Плисенко Г. П. Брендинг і бренд-білдінг як найважливіші інструменти в конкуренції на ринку освітніх послуг. Вісник Київського національного університету технологій та дизайну. Серія : Економічні науки. 2016. № 4 (101). C. 41-47.

5. Поплавський М. М. Ректор. Київ : Р.К. Майстер-принт, 2017. 488 с. : іл.

6. Семенюк С. Брендинг вищого навчального закладу. Галицький економічний вісник. 2013. № 3 (42). С.133-138. 
7. Фукуяма Ф. Теоретические основы профессиональной ориентации. Москва : МГУ, 1989. 108 с.

8. James P., Sampson Jr., Watts, A. G., Palmer M., Hughes, D. International collaboration in translating career theory to practice. The Career Development Quarterly. 2000. Vol. 48. pp. 332-339. https://doi.org/10.1002/j.2161-0045.2000. tb00878.x

9. Watts A. G. Strategic Directions for Career Services in Higher Education. Cambridge: AGCAS/NICEC/CRAC, 1997. $60 \mathrm{p}$.

10. Wheeler A. Designing Brand Identity: An Essential Guide for the Entire Branding Team. New Jersey : John Wiley \& Sons, Ins., Hoboken, 2003. 310 p. 